\section{REVIEW ARTICLE}

\title{
Trojan Horses of the microbial world: protozoa and the survival of bacterial pathogens in the environment
}

\author{
J. Barker' and M. R. W. Brown ${ }^{2}$
}

Author for correspondence: J. Barker. Tel : +44742533 004. Fax: + 44742532020.

'Department of Biomedical Sciences, Sheffield Hallam University, Pond Street, Sheffield S1 1WB, UK

2Pharmaceutical Sciences Institute, Aston University, Aston Triangle, Birmingham B4 7ET, UK

Keywords: biofilms, intra-amoebal growth, legionella, listeria, protozoa

\section{The resistance of bacteria to protozoal predation}

Protozoa, of which there are thousands of species, are ubiquitous in diverse natural habitats such as fresh and salt water, moist soils and even dry sands. The role of freeliving protozoa in terrestrial and aquatic environments as predators of bacteria is widely acknowledged. Predation by protozoa has a significant effect in controlling bacterial populations in soil, and the degradation of bacteria undoubtedly contributes to the maintenance of soil fertility (Foster \& Dormaar, 1991; Weekers et al., 1993). Likewise, protozoa play an integral part in the cycling of nutrients in aquatic food chains (Porter, 1984; Wright \& Coffin, 1984).

However, it is clear from other studies concerning the interaction of bacteria and protozoa that not all bacteria are suitable food sources for amoebae (Singh, 1942, 1946; Danso \& Alexander, 1975; Weekers et al., 1993). Alexander (1981) reported that some Gram-negative bacteria were able to survive grazing by protozoa, which could be due to the inability of the amoebae to take-up or to kill and digest internalized bacteria. Alternatively, bacteria may be able to resist engulfment by defence mechanisms such as toxins, toxic pigments or outer-membrane structures (Weekers et al., 1993). There has been a number of reports (Preer et al., 1974; Hall \& Voelz, 1985; Fritsche et al., 1993) of bacteria surviving as endosymbionts of free-living protozoa, thus demonstrating adaptation to the intracellular environment. The discovery that Legionella pneumophila infects and multiplies within some species of free-living amoebae (Rowbotham, 1980) has confirmed the ability of bacteria to exploit a normally hostile intracellular environment to ensure survival. Indeed, survival and intracellular growth of bacterial species in protozoa may well prime pathogenic bacteria for virulence. However, the potential role of protozoa as reservoirs for human pathogens does not appear to have received adequate attention. This article examines the importance of protozoa in the maintenance, survival and protection of pathogenic bacteria in natural and manmade ecosystems.

\section{Protozoa and interactions with bacterial pathogens \\ Legionellaceae}

Although at least 34 Legionella species have been identified, Leg. pneumophila is the primary cause of Legionnaires' disease, a serious form of atypical pneumonia. Leg. pneumophila can infect and multiply within Hartmannella, Acantbamoeba and Naegleria species, which are ubiquitous in moist soil and aquatic environments (see Table 1). Legionellae can also survive and multiply within ciliated protozoa of the genus Tetrabymena, a freshwater bacteriovore (Fields et al., 1984). Following phagocytosis by acanthamoebae, legionellae multiply within the cytoplasm, evading the host lysosomal attack so that after 36-48 h a single vesicle of motile legionellae fills most of the amoebal cell. The final effect of infection is lysis of the cell and liberation of many motile bacteria into the environment. Rowbotham (1986) has studied electron micrographs of Leg. pneumopbila growing within Acanthamoeba polyphaga in the later stages of infection. It has been estimated that an amoebal vesicle of $10 \mu \mathrm{m}$ diameter, with $90 \%$ of the space occupied by bacteria measuring $0.32 \times 0.60 \mu \mathrm{m}$, could contain approximately $10^{4}$ bacterial cells. Leg. pneumophila is now known to infect five genera of amoebae (Fields, 1993), whereas other species of Legionella have a more specialized host range (Fields et al., 1990).

Recently, a group of legionella-like amoebal pathogens (LLAPs) have been reported (Rowbotham, 1993), which are bacilli that infect and multiply in the cytoplasm of amoebae but so far have not been found to grow on laboratory media. LLAPs may be of considerable importance because they are capable of causing pneumonia and induce a serological response in infected patients 
Table 1. Bacterial pathogens surviving within protozoa

\begin{tabular}{|c|c|c|c|}
\hline Bacterial species & Protozoal host & $\begin{array}{c}\text { Outcome of protozoal } \\
\text { uptake }\end{array}$ & Selected references \\
\hline Legionella pneumophila & $\begin{array}{l}\text { Acanthamoeba } \\
\text { Naegleria }\end{array}$ & Multiplication, cell lysis & Rowbotham (1980) \\
\hline Legionella pneumopbila & Tetrabymena & Multiplication, cell lysis & Fields et al. (1984) \\
\hline $\begin{array}{l}\text { Legionella-like amoebal } \\
\text { pathogens (LLAPs) }\end{array}$ & $\begin{array}{l}\text { Acanthamoeba } \\
\text { Hartmannella }\end{array}$ & Multiplication, cell lysis & Rowbotham (1993) \\
\hline Listeria monocytogenes & $\begin{array}{l}\text { Acanthamoeba } \\
\text { Tetrabymena }\end{array}$ & $\begin{array}{l}\text { Multiplication, cell lysis } \\
\text { Multiplication, cell lysis }\end{array}$ & $\begin{array}{l}\text { Ly \& Müller }(1990 a) \\
\text { Ly \& Müller }(1990 b)\end{array}$ \\
\hline Vibrio cholerae & $\begin{array}{l}\text { Acanthamoeba } \\
\text { Naegleria }\end{array}$ & Multiplication & Thom et al. (1992) \\
\hline $\begin{array}{l}\text { Edwardsiella tarda } \\
\text { Aeromonas salmonicida } \\
\text { (Fish pathogens) }\end{array}$ & Tetrabymena & Multiplication & $\begin{array}{l}\text { King \& Shotts } \\
\text { (1988) }\end{array}$ \\
\hline Mycobacterium leprae & Acanthamoeba & Survival & Jadin (1975) \\
\hline Opportunist mycobacteria & Acanthamoeba & Survival & $\begin{array}{l}\text { Krishna-Prasad \& } \\
\text { Gupta (1978) }\end{array}$ \\
\hline $\begin{array}{l}\text { Pseudomonas, Alcaligenes } \\
\text { and Bacillus species }\end{array}$ & Hartmannella & Survival & Tyndall et al. (1991) \\
\hline $\begin{array}{l}\text { Coliform organisms } \\
\text { (including Salmonella } \\
\text { typbimurium) }\end{array}$ & $\begin{array}{l}\text { Tetrabymena } \\
\text { Acantbamoeba }\end{array}$ & Survival & King et al. (1988) \\
\hline
\end{tabular}

(Rowbotham, 1993). PCR studies of amplified DNA coding for the $16 \mathrm{~S}$ rRNA of LLAP (type 3) have shown that this organism is a member of the genus Legionella (Fry et al., 1991). Based on rRNA analysis it has been suggested that LLAPs may be a new group of Legionella (Rowbotham, 1993) and that they are closely related to Sarcobium lyticum, an obligate intracellular parasite of soil amoebae, first described in Poland by Drozanski (1991).

Although the interactions between legionellae and amoebae were observed in vitro with axenically grown amoebae (Rowbotham, 1980), it has been shown that amoebae isolated directly from river-water sediment contained Leg. pneumophila after they were washed and lysed (Harf et al., 1987). More recently, soil amoebae of the genus Vablkampfia and Hartmannella were found to be infected by Leg. longbeachae (Steele, 1993). Dry potting soil compost containing such amoebae has been associated with a number of cases of pneumonia in Southern Australian states caused by Leg. longbeachae. It is now apparent that intra-protozoal growth of legionellae is a primary mechanism for the survival and multiplication of the bacterium in natural habitats (Wadowsky et al., 1988; Fields et al., 1989) and that Legionella are not simply and only free-living bacteria per se, but have a highly evolved host/parasite relationship, described as protozootic (Rowbotham, 1993), for their survival in natural ecosystems.

\section{Other bacterial species surviving in amoebae}

Legionella are not the only human pathogens capable of survival in protozoal hosts (see Table 1). Reports suggest that the fate of internalized bacteria falls into three main groups; those which multiply and cause lysis of amoebal cells such as Legionella and Listeria; those which multiply without causing cell lysis (Vibrio cholerae); and those which survive without multiplication (certain coliform organisms and mycobacteria).

Listeria are a diverse group of environmental bacteria often considered to be soil micro-organisms (Seeliger, 1988), but some species infect humans and other mammals and invade host cells, including macrophages. Ly \& Müller (1990a) reported that Listeria monocytogenes infection of Acanthamoeba castellanii causes cell lysis and death. L. monocytogenes can also grow in coculture with Tetrabymena pyriformis and causes cell lysis after $8-15 \mathrm{~d}$ incubation (Ly \& Müller, 1990b). Panikov et al. (1993) have confirmed that $L$. monocytogenes grows within $T$. pyriformis and calculated a generation time of $14.4 \mathrm{~h}$, compared to a generation time of $7 \mathrm{~h}$ for legionellae. $\mathrm{L}$. monocytogenes infects nutrient-depleted axenic cultures of $A$. polyphaga, resulting in a $1-2 \log$ increase in numbers after $3 \mathrm{~d}$ incubation ( $\mathrm{J}$. Barker, unpublished data). The infection appears to induce formation of thin-walled precysts containing many motile listeria.

Other environmental bacteria capable of growth in $T$. pyriformis include Edwardsiella tarda and Aeromonas salmonicida, two common bacterial fish pathogens (King \& Shotts, 1988). In addition, environmental species of opportunist mycobacteria (including Mycobacterium avium) survive within $A$. castellanii and when amoeba-cell division occurs, ingested bacteria are passed to the progeny (Krishna-Prasad \& Gupta, 1978). Jadin (1975) has found that Mycobacterium leprae is capable of growth in Acantbamoeba culbertsoni and suggested that free-living 
amoebae may be environmental vectors for mycobacteria including M. Leprae (Jadin, 1987).

Further evidence of the role of amoebae in the maintenance of pathogens in the environment has been reported by Thom et al. (1992), who found that $V$. cholerae multiplied after ingestion by Naegleria and Acanthamoeba species. $V$. cholerae also survived within cysts of Naegleria and was recovered from the excysting amoeba. Freeliving amoebae may help to maintain $V$. cholerae in natural waters in parts of the world where there is no evident association with cases of clinical cholera (Colwell et al., 1977; Bashford et al., 1979), thus acting as reservoirs for possible cholera infections.

\section{Protozoa: their role in the protection of environmental bacteria}

Bacteria internalized by protozoa may be given unique protection when the protozoa form cysts. Under adverse conditions, Rowbotham (1986) observed that Acanthamoeba containing legionellae encyst, leading to the formation of a precyst or a mature thick-walled cyst which traps motile or non-motile legionellae. Legionella species have been detected in sewage works and concentrations were not appreciably reduced by either primary or secondary treatment processes (Palmer et al., 1993). This finding could be related to the protection provided by protozoa which are ubiquitous inhabitants of sewagetreatment plants. The resistance of amoebal cysts to extremes of temperature (Chang, 1978; Biddick et al., 1984 ) and to the effects of biocides (De Jonckheere \& Van de Voorde, 1976) may contribute to the difficulties in eradicating legionellae from contaminated water systems using conventional disinfectant procedures. $A$. polyphaga cysts infected with Leg. pneumophila protected the bacterium from the action of chlorine (Kilvington \& Price, 1990) and isothiazolone biocides (Kilvington, 1990); bacteria were recovered from excysting amoebae. Not only does the amoebal cyst offer a mechanism for bacteria to evade hostile environmental conditions, but it also provides a means by which the bacteria can spread and colonize new habitats by it being blown through the air (Kingston \& Warhurst, 1969).

Coliform bacteria internalized by protozoa in natural ecosystems may give protection against external antagonists (King et al., 1988). Salmonella typhimurium and Shigella sonnei survived ingestion by laboratory strains of $A$. castellanii and $T$. pyriformis and were shielded from the activity of free chlorine. Bacteria were cultured from chlorine-treated protozoans well after the time required for $99 \%$ inactivation of extracellular cells. Thus, organisms trapped within amoebae could be responsible for the persistence of coliform bacteria in chlorine-treated water supplies (Goshko et al., 1983; Hudson et al., 1983). The role of free-living amoebae in harbouring environmental bacteria has been confirmed by the presence of heterotrophs, including Pseudomonas and Alcaligenes species, isolated from Hartmannella trophozoites and cysts, found in well-water samples (Tyndall et al., 1991).
The control and eradication of $L$. monocytogenes in food production is a continuing problem, as Listeria are often isolated from moist surfaces in food-processing plants (Frank et al., 1990; Nelson, 1990). The isolation of these organisms highlights problems in cleaning and disinfection, but a contributory factor to the survival of the organism's in such environments is likely to be through association with adherent biofilms (Ren \& Frank, 1993). Although it is widely acknowledged that biofilm bacteria are generally more resistant to treatment with biocides (Costerton et al., 1987; Gilbert et al., 1990), Listeriae ingested or encysted by amoebae would have an increased chance of surviving disinfection procedures. Yet the possible role of free-living amoebae in promoting the survival of Listeria in the environment has not been explored.

Recently eye-wash stations in hospitals were found to contain Leg. pneumophila, Pseudomonas species and Acanthamoeba (Paszko-Kolva et al., 1991). The presence of the Acantbamoeba probably had a significant role in allowing the bacterial species to survive, as amoebal lysis resulting from infection with legionellae would release nutrients, encouraging the growth of other bacteria.

As well as providing physical protection from adverse conditions, growth in amoebae may alter the physiology of bacteria. Leg. pneumophila cells grown within Acanthamoeba and then freed from the amoebal host were significantly resistant to treatment with biocides compared to bacteria grown in vitro (Barker et al., 1992). For example, only a 10-fold kill was achieved with an isothiazolone derivative against intra-amoebal-grown legionellae, whereas a 1000-fold kill was observed for cells grown in vitro. Intra-amoebal growth may also affect bacterial survival after the death of the host. Leg. pneumophila has been recovered after growth in $A$. polyphaga and storage at $4{ }^{\circ} \mathrm{C}$ for 6 months with only small reductions in the viable count ( $\mathrm{J}$. Barker, unpublished data). These results are compatible with the finding that the physiology of legionellae has altered as a result of their growth within the amoebae and produced a radically altered phenotype (Barker et al., 1993).

\section{Bacterial survival within host protozoa}

Although some bacterial species survive ingestion by protozoa, under certain environmental conditions the same organisms are eradicated. At low temperatures acanthamoebae may phagocytose and digest Leg. pneumophila as food (Anand et al., 1983), or evict the phagosomes containing legionellae as faecal vesicles (T. Rowbotham, personal communication). Alternatively, at higher temperatures after infection with the same strain of Legionella, the amoebae can be heavily parasitized so that after $24 \mathrm{~h}$ they become packed with motile legionellae. Growth temperature may be an important factor in determining the virulence of Leg. pneumophila. Mauchline et al. (1993) have shown that in continuous culture, under defined conditions, Leg. pneumophila maintains its virulence in animal pathogenicity tests. When the growth temperature 
was decreased from $37{ }^{\circ} \mathrm{C}$ to $24^{\circ} \mathrm{C}$, virulence was attenuated because none of the animals died.

As with other micro-organisms the virulence of Legionella species is almost certainly governed by the products of many genes (Miller et al., 1989). The molecules of potential importance to the intracellular survival of Leg. pneumopbila have been extensively reviewed (Dowling et al., 1992; Horwitz, 1993; Hacker et al., 1993). However, the uptake of bacteria by protozoal hosts is an important stage in the infective process. Previous studies (King et al., 1991) have indicated that Leg. pneumophila infects Hartmannella vermiformis by a microfilament-independent mechanism (it is not inhibited by cytochalasin D). Conversely, an inhibitor of adsorptive pinocytosis (methylamine) blocked infection of $H$. vermiformis, which suggests that receptormediated endocytosis is necessary for infection of the amoebae. Further work by Fields et al. (1993) has indicated that entry, not attachment, of virulent Leg. pneumophila is the limiting step in infection of axenically grown $H$. vermiformis. Hodinka \& Wyrick (1986) have described receptor-mediated endocytosis as a means of avoiding phagosome/lysosome fusion for chlamydiae in mouse fibroblast (L-929) cells. This method of uptake is suspected to direct the organism into vesicles that do not fuse with the lysosome.

Ultrastructural examination of infected Hartmannella has revealed that, immediately after ingestion, single Leg. pneumophila cells are found in endosomes. It has been suggested by Fields (1993) that in $H$. vermiformis, the endosome containing the legionellae fuses with the endoplasmic reticulum of the host cell and that this becomes the site for bacterial multiplication. An examination of the uptake of the intracellular parasite Brucella by Vero-cells has revealed that it multiplies within the endoplasmic reticulum and so avoids attack by lysozyme enzymes (Detilleux et al., 1990).

\section{Protozoa, biofilms and bacterial evolution}

The importance of biofilms in the maintenance and survival of micro-organisms in the general environment is widely acknowledged (Costerton et al., 1987; Characklis \& Marshall, 1990). Biofilms not only serve to allow for the growth of micro-organisms in water systems but also protect from antimicrobial substances (Keevil et al., 1990; Brown \& Gilbert, 1993). Biofilms are a major source of Legionella species in both man-made (Rowbotham, 1993) and natural aquatic systems (Marrao et al., 1993). The concentration of bacteria within the biofilms provides excellent opportunities for attack by predators, such as protozoa, and parasites, such as bacteriophages and Bdellovibrio species (Characklis et al., 1990). The biofilm/ water interface also attracts ciliates, flagellates and amoebae, which graze the surface, seeking food. Although Legionella is an effective parasite of certain species of protozoa, it in turn is susceptible to predation by Bdellovibrio (Tomov et al., 1982; Richardson, 1990), a bacterium associated with the biofilm environment (Starr \& Seidler, 1971). Perhaps it should be no surprise that environmental bacteria such as Legionella, Listeria and
Vibrio species have evolved so that they are capable of surviving and multiplying within biofilm predators such as amoebae, as it offers protection in adverse conditions. Indeed it has been suggested (King et al., 1988) that resistance to digestion by predatory protozoa was an evolutionary prerequisite of bacterial pathogenicity and a survival mechanism for bacteria in aquatic environments. In support of this hypothesis, Cianciotto \& Fields (1992) have reported that the Leg. pneumophila mip gene potentiates intracellular infection of protozoa and human macrophages. The mip gene (Cianciotto et al., 1989), which is responsible for the production of a $24 \mathrm{kDa}$ surface protein, appears to be required for optimal intracellular infection and may be involved in resistance to intracellular killing. Thus the ability of Leg. pneumophila to parasitize macrophages and hence to cause human disease may be a consequence of its adaptation to intracellular growth within protozoa. Mip analogues have been found in other intracellular parasites, including Coxiella, Chlamydia and Neisseria (Bangsborg et al., 1991; Dumais-Pope et al., 1993). It would be tempting to speculate that Mip-related proteins are critical for the virulence of intracellular pathogens. However, virulence of intracellular parasites is almost certainly multifactorial and not dependent on the expression of individual phenotypic traits (Horwitz, 1993). The bacterial pathogens capable of survival and/or multiplication in protozoa include Listeria, Legionella, Mycobacterium and Vibrio. With the exception of $V$. cholerae their pathogenesis in the human host involves intracellular invasion and replication in phagocytic cells. However, it has been noted that in a study of the phylogenic relationship between Chlamydia, an obligate intracellular parasite, and other bacteria, that ribosomal RNA from Cblamydia hybridized preferentially with DNA from $V$. cholerae (Palme \& Falkow, 1986).

\section{Concluding remarks}

Although the evolutionary role of protozoa in the development of bacterial pathogenesis is debatable, there is no doubt of the importance of bacteria/protozoa interactions in terms of human disease. They allow survival, replication and distribution of some species of pathogenic bacteria in the natural environment. The intracellular niche affords protection against adverse environmental conditions and treatment with biocides, such as chlorine. It has been suggested that amoebae may act as vectors for the direct transmission of Leg. pneumophila to the human host, through inhalation of amoebal vesicles containing bacilli (Rowbotham, 1992; O’Brien \& Bhopal, 1993).

Intra-amoebal growth of bacteria may induce phenotypes that are considerably different from in-vitro-grown strains in terms of physiological status, survival and infectivity. The cell morphology and protein, lipopolysaccharide and fatty acid content of Leg. pneumophila after growth within $A$. polyphaga, was found to differ considerably from cells grown in vitro (Barker et al., 1993). Bacteria grown on Legionella agar after cocultivation with acanthamoebae reverted to the morphological phenotype associated with in vitro conditions (typically nonmotile and filamentous), 
whereas, intra-protozoal growth induced legionellae that are morphologically similar to those observed within macrophages, i.e. small and highly motile (King et al., 1991). The changes in the molecular composition of intraamoebal-grown bacteria could be important to infection processes in the human host because it is well established that surface molecules play a vital role in bacterial survival and virulence (Brown \& Williams, 1985). Indeed, it is tempting to speculate that protozoa could be used as alternatives to macrophages and other animal cell-lines for studying the virulence characteristics of obligate intracellular parasites such as Chlamydia, Coxiella or even M. leprae.

Amoebae are an integral part of natural and man-made water systems and they will not be easily controlled or eradicated. Their role in the maintenance of human disease such as legionellosis has only recently been acknowledged and their role in the survival and distribution of other pathogenic bacteria has received scant attention. Yet these host/parasite interactions may be of considerable importance to the maintenance of infectious agents in the environment. Furthermore, intra-protozoal growth of bacteria may well optimize their potential for virulence: inside the protozoal 'Horse' they may be adapting to the human 'Troy'.

We would like to thank Dr T. Rowbotham for helpful discussions on this topic.

\section{References}

Alexander, M. (1981). Why microbial predators and parasites do not eliminate their prey and hosts. Annu Rev Microbiol 35, 113-133.

Anand, C. M., Skinner, A. R., Malic, A. \& Kurtz, J. B. (1983). Interaction of Legionella pneumopbila and free living amoebae (Acanthamoeba palestinensis). J Hyg (Camb) 91, 167-178.

Bangsborg, J. M., Cianciotto, N. P. \& Hindersson, P. (1991). Nucleotide sequence analysis of the Legionella micdadei mip gene, encoding a 30-kilodalton analog of the Legionella pneumopbila Mip protein. Infect Immun 59, 3836-3840.

Barker, J., Brown, M. R. W., Collier, P. J., Farrell, I. D. F. \& Gilbert, P. (1992). Relationship between Legionella pneumophila and Acantbamoeba polyphaga: physiological status and susceptibility to chemical inactivation. Appl Environ Microbiol 58, 2420-2425.

Barker, J., Lambert, P. A. \& Brown, M. R. W. (1993). The influence of intra-amoebic and other growth conditions on the surface properties of Legionella pneumophila. Infect Immun 61, 3503-3510.

Bashford, D. J., Donovan, T. J., Furniss, A. L. \& Lee, J. V. (1979). Vibrio cholerae in Kent. Lancet 1, 436-437.

Biddick, C. J., Rogers, L. H. \& Brown, T. J. (1984). Viability of pathogenic and nonpathogenic free-living amoebae in long-term storage at a range of temperatures. Appl Environ Microbiol 48, 859-860.

Brown, M. R. W. \& Williams, P. (1985). The influence of environment on envelope properties affecting survival of bacteria in infections. Annu Rev Microbiol 39, 527-556.

Brown, M. R. W. \& Gilbert, P. (1993). The sensitivity of biofilms to antimicrobial agents. J Appl Bacteriol 74 (Suppl), 87S-97S.

Chang, S. L. (1978). Resistance of pathogenic Naegleria to some common physical and chemical agents. Appl Environ Microbiol 35, 368-375.
Characklis, W. G. \& Marshall, K. C. (1990). Biofilms: a basis for an interdisciplinary approach. In Biofilms, pp. 3-15. Edited by W. G. Characklis \& K. G. Marshall. New York: John Wiley \& Sons.

Characklis, W. G., McFeters, G. A. \& Marshall, K. C. (1990). Physiological ecology in biofilm systems. In Biofilms, pp. 361. Edited by W. G. Characklis \& K. G. Marshall. New York: John Wiley \& Sons.

Cianciotto, N. P. \& Fields, B. S. (1992). Legionella pneumophila mip gene potentiates intracellular infection of protozoa and human macrophages. Proc Natl Acad Sci US A 89, 5188-5191.

Cianciotto, N. P., Eisenstein, B. J., Mody, C. H., Toews, G. B. \& Engleberg, N. C. (1989). A Legionella pneumophila gene encoding a species-specific surface protein potentiates initiation of intracellular infection. Infect Immun 57, 1255-1262.

Colwell, R. R., Kaper, J. \& Joseph, S. W. (1977). Vibrio cholerae, Vibrio parabaemolyticus and other vibrios: occurrence and distribution in Chesapeake Bay. Science 198, 394-396.

Costerton, J. W., Cheng, K. J., Geesey, G. G., Ladd, T. I., Nickel, J. C., Dasgupta, M. \& Marrie, T. J. (1987). Bacterial biofilms in nature and disease. Annu Rev Microbiol 41, 435-464.

Danso, S. A. K. \& Alexander, M. (1975). Regulation of predation by prey density: the protozoan-rhizobium relationship. Appl Microbiol 29, 515-521.

De Jonckheere, J. F. \& Van de Voorde, H. (1976). Differences in destruction of cysts of pathogenic and nonpathogenic Naegleria and Acanthamoeba by chlorine. Appl Environ Microbiol 31, 294-297.

Detilleux, P. G., Deyoe, B. L. \& Cheville, N. F. (1990). Entry and intracellular localization of Brucella spp. in Vero cells: fluorescence and electron microscopy. Vet Pathol 27, 317-328.

Dowling, J. N., Saha, A. K. \& Glew, R. H. (1992). Virulence factors of the family Legionellaceae. Microbiol Rev 56, 32-60.

Drozanski, W. (1991). Sarcobium lyticum gen. nov., sp. nov., an obligate intracellular parasite of small free-living amoebae. Int J Syst Bact 41, 82-87.

Dumais-Pope, C., O'Connell, W. \& Cianciotto, N. P. (1993). Distribution and regulation of the Legionella mip gene. In Legionella: Current Status and Emerging Perspectives, pp. 70-72. Edited by J. M. Barbaree, R. F. Breiman \& A. P. Dufour. Washington, DC: American Society for Microbiology.

Fields, B. S. (1993). Legionella and protozoa: interaction of a pathogen and its natural host. In Legionella: Current Status and Emerging Perspectives, pp. 70-72. Edited by J. M. Barbaree, R. F. Breiman \& A. P. Dufour. Washington, DC: American Society for Microbiology.

Fields, B. S., Shotts, E. B., Feeley, J. C., Gorman, G. W. \& Martin, W. T. (1984). Proliferation of Legionella pneumophila as an intracellular parasite of the ciliated protozoan Tetrabymena pyriformis. Appl Environ Microbiol 47, 467-471.

Fields, B. S., Sanden, G. N., Barbaree, J. M., Morrill, W. E., Wadowsky, R. M., White, E. H. \& Feeley, J. C. (1989). Intracellular multiplication of Legionella pneumopbila in amoebae isolated from hospital hot water tanks. Curr Microbiol 18, 131-137.

Fields, B. S., Barbaree, J. M., Sanden, G, N. \& Morrill, W. E. (1990). Virulence of a Legionella anisa strain associated with Pontiac fever: an evaluation using protozoan, cell culture, and guinea pig models. Infect Immun 58, 3139-3142.

Fields, B. S., Utley Fields, S. R., Chin Loy, J. N., White, E. H., Steffens, W. L. \& Shotts, E. B. (1993). Attachment and entry of Legionella pneumophila in Hartmannella vermiformis. J Infect Dis 167, 1146-1150.

Foster, R. C. \& Dormaar, J. F. (1991). Bacteria-grazing amoebae in situ in the rhizosphere. Biol Fertil Soils 11, 83-87. 
Frank, J. F., Gillett, R. A. N. \& Ware, G. O. (1990). Association of Listeria spp. contamination in the dairy processing plant environment with the presence of staphylococci. J Food Prot 53, 928-932.

Fritsche, T. R., Gautom, R. K., Seyedirashti, S., Bergeron, D. L. \& Lindquist, T. D. (1993). Occurrence of bacterial endosymbionts in Acanthamoeba spp. isolated from corneal and environmental specimens and contact lenses. J Clin Microbiol 31, 1122-1126.

Fry, N. K., Rowbotham, T. J., Saunders, N. A. \& Embley, T. M. (1991). Direct amplification and sequencing of the $16 \mathrm{~S}$ ribosomal DNA of an intracellular Legionella species recovered by amoebal enrichment from the sputum of a patient with pneumonia. FEMS Microbiol Lett 83, 165-168.

Gilbert, P., Collier, P. J. \& Brown, M. R. W. (1990). Influence of growth rate on susceptibility to antimicrobial agents: biofilms, cell cycle, dormancy and stringent response. Antimicrob Agents Chemother 34, 1865-1868.

Goshko, M. S., Pipes, W. D. \& Christian, R. R. (1983). Coliform occurrence and chlorine residual in small water distribution systems. J Am Water Works Assoc 75, 309-312.

Hacker, J., Ott, M., Wintermeyer, E., Ludwig, B. \& Fischer, G. (1993). Analysis of virulence factors of Legionella pneumophila. Zentralbl Bakteriol 278, 348-358.

Hall, J. \& Voelz, H. (1985). Bacterial endosymbionts of Acanthamoeba spp. J Parasitol 71, 89-95.

Harf, C., Monteil, H. \& Vetter, M. T. (1987). Relations amibes libres - Legionella dans l'environnement. In Collection Fondation Faulte M. Merieux, pp. 139-143. Edited by J. Fleurette, N. Bornstein, D. Marmet \& M. Surgot. Lyon: Colloque Legionella 6-7 mai 1987.

Hodinka, R. L. \& Wyrick, P. B. (1986). Ultrastructural study of mode of entry of Chlamydia psittaci into L-929 cells. Infect Immun 54, 855-863.

Horwitz, M. A. (1993). Toward an understanding of host and bacterial molecules mediating Legionella pneumophila pathogenesis. In Legionella: Current Status and Emerging Perspectives, pp. 55-62. Edited by J. M. Barbaree, R. F. Breiman \& A. P. Dufour. Washington, DC: American Society for Microbiology.

Hudson, L. D., Hankins, J. W. \& Battaglia, M. (1983). Coliforms in a water distribution system: a remedial approach. $J A m$ Water Works Assoc 75, 564-568.

Jadin, J. B. (1975). Amibes limax vecteurs possible de Mycobacteries et de $M$. leprae. Acta Leprol 59, 57-67.

Jadin, J. B. (1987). History. In Infectious Diseases Colour Atlas Monographs. 1. Amphizoic Amoebae: Human Patbology, pp. 1-32. Edited by E. G. Rondanelli. Italy: Piccin Nuova Libraria.

Keevil, C. W., Mackerness, C. W. \& Colbourne, J. S. (1990). Biocide treatment of biofilms. Int Biodeterior 26, 169-179.

Kilvington, S. (1990). Activity of water biocide chemicals and contact lens disinfectants on pathogenic free-living amoebae. Int Biodeterior 26, 127-138.

Kilvington, S. \& Price, J. (1990). Survival of Legionella pneumophila within Acanthamoeba polyphaga cysts following chlorine exposure. $J$ Appl Bacteriol 68, 519-525.

King, C. H. \& Shotts, E. B., Jr (1988). Enhancement of Edwardsiella tarda and Aeromonas salmonicida through ingestion by the ciliated protozoan Tetrabymena pyriformis. FEMS Microbiol Lett 51, 95-100.

King, C. H., Shotts, E. B., Jr, Wooley, R. E. \& Porter, K. G. (1988). Survival of coliforms and bacterial pathogens within protozoa during chlorination. Appl Environ Microbiol 54, 3023-3033.

King, C. H., Fields, B. S., Shotts, E. B., Jr \& White, E. H. (1991). Effects of cytochalasin $\mathrm{D}$ and methylamine on intracellular growth of Legionella pneumophila in amoebae and human monocyte-like cells. Infect Immun 59, 758-763.

Kingston, D. \& Warhurst, D. C. (1969). Isolation of amoebae from the air. J Med Microbiol 2, 27-36.

Krishna-Prasad, B. N. \& Gupta, S. K. (1978). Preliminary report on engulfment and retention of mycobacteria by trophozoites of axenically grown Acanthamoeba castellanii Douglas, 1930. Curr Sci 47, 245-247.

Ly, T. M. C. \& Müller, H. E. (1990a). Interactions of Listeria monocytogenes, Listeria seeligeri and Listeria innocua with protozoans. $J$ Gen Appl Microbiol 36, 143-150.

Ly, T. M. C. \& Müller, H. E. (1990b). Ingested Listeria monocytogenes survive and multiply in protozoa. $J$ Med Microbiol 33, 51-54.

Marrao, G., Verissimo, A., Bowker, R. G. \& da Costa, M. S. (1993). Biofilms as major sources of Legionella spp. in hydrothermal areas and their dispersion into streams. FEMS Microbiol Ecol 12, 25-33.

Mauchline, W. S., Araujo, R., Fitzgeorge, R. B., Dennis, P. J. \& Keevil, C. W. (1993). Environmental regulation of the virulence and physiology of Legionella pneumophila. In Legionella: Current Status and Emerging Perspectives, pp. 262-264. Edited by J. M. Barbaree, R. F. Breiman \& A. P. Dufour. Washington, DC: American Society for Microbiology.

Miller, J. F., Mekalanos, J. J. \& Falkow, S. (1989). Coordinate regulation and sensory transduction in the control of bacterial virulence. Science 243, 916-922.

Nelson, H. H. (1990). Where are Listeria likely to be found in dairy plants? Dairy Food Sanit 10, 344-345.

O'Brien, S. J. \& Bhopal, R. S. (1993). Legionnaires' disease: the infective dose paradox. Lancet 342, 5-6.

Palme, L. \& Falkow, S. (1986). Characterization of cloned genes from Chlamydia trachomatis. In Microbiology-1986, pp. 91-95. Edited by L. Lieve, P. F. Bonventre, J. A. Morello, S. D. Silver \& H. C. Wu. Washington, DC: American Society for Microbiology.

Palmer, C. J., Tsai, Y., Paszko-Kolva, C., Mayer, C. \& Sangermano, L. R. (1993). Detection of Legionella species in sewage and ocean water by polymerase chain reaction, direct fluorescent-antibody, and plate culture methods. Appl Environ Microbiol 59, 3618-3624.

Panikov, N. S., Merkurov, A. S. \& Tartakovkii, I. S. (1993). Kinetic studies of Legionella interactions with protozoa. In Legionella: Current Status and Emerging Perspectives, pp. 153-156. Edited by J. M. Barbaree, R. F. Breiman \& A. P. Dufour. Washington, DC: American Society for Microbiology.

Paszko-Kolva, C., Yamamoto, H., Shahmat, M., Sawyer, T. K., Morris, G. \& Colwell, R. R. (1991). Isolation of amoebae and Pseudomonas and Legionella spp. from eyewash stations. Appl Environ Microbiol 57, 163-167.

Porter, K. G. (1984). Natural bacteria as food resources for zooplankton. In Current Perspectives in Microbial Ecology, pp. 340-345. Edited by M. A. Klug \& C. A. Reddy. Washington, DC: American Society for Microbiology.

Preer, J. R., Preer, L. B. \& Jurand, A. (1974). Kappa and other endosymbionts in Paramecium aurelia. Bacteriol Rev 38, 113-163.

Ren, T. \& Frank, J. F. (1993). Susceptibility of starved planktonic and biofilm Listeria monocytogenes to quaternary ammonium sanitizer as determined by direct viable and agar plate counts. J Food Prot 56, 573-576.

Richardson, I. R. (1990). Legionella under attack! The incidence of Bdellovibrio spp. in man-made water systems: coexistence with legionellas. In Proceedings of the 15th Annual Scientific Conference, Public Health Laboratory Service, Winchester.

Rowbotham, T. J. (1980). Preliminary report on the pathogenicity 
of Legionella pneumopbila for freshwater and soil amoebae. J Clin Pathol 33, 1179-1183.

Rowbotham, T. J. (1986). Current views on the relationship between amoeba, legionellae and man. Israel J Med Sci 22, 678-689.

Rowbotham, T. J. (1992). Little and large particle theory for legionellosis acquired from polymicrobial sources. In Proceedings of the International Symposium on Legionella. Florida: American Society for Microbiology.

Rowbotham, T. J. (1993). Legionella-like amoebal pathogens. In Legionella: Current Status and Emerging Perspectives, pp. 137-140. Edited by J. M. Barbaree, R. F. Breiman \& A. P. Dufour. Washington, DC: American Society for Microbiology.

Seeliger, H. P. R. (1988). Listeriosis - history and actual developments. Infection 16, 580-584.

Singh, B. N. (1942). Selection of bacterial food by soil flagellates and amoebae. Ann Appl Biol 29, 18-22.

Singh, B. N. (1946). A method of estimating the numbers of soil protozoa, especially amoebae, based on their differential feeding on bacteria. Ann Appl Biol 33, 112-119.

Starr, M. P. \& Seidler, R. J. (1971). The Bdellovibrios. Annu Rev Microbiol 25, 649-678.

Steele, T. W. (1993). Interactions between soil amoebae and soil legionellae. In Legionella: Current Status and Emerging Perspectives, pp. 140-142. Edited by J. M. Barbaree, R. F. Breiman \& A. P. Dufour. Washington, DC: American Society for Microbiology.

Thom, S., Warhurst, D. \& Drasar, B. S. (1992). Association of Vibrio cholerae with fresh water amoebae. J Med Microbiol 36, 303-306.

Tomov, A., Kassovsky, V., Chorbadjiska, L., Tsvetkova, E., Tasnev, N. \& Vencheva, Z. (1982). Lytic activity of Bdellovibrio bacteriovorous against bacteria of the family Legionellaceae. Zentralbl Backteriol Mikrobiol Hyg (A) 252, 96-100.

Tyndall, R. L., Ironside, K. S., Little, C. D., Katz, D. S. \& Kennedy, J. R. (1991). Free-living amoebae used to isolate consortia capable of degrading trichloroethylene. Appl Biochem Biotechnol 28/29, 917-925.

Wadowsky, R. M., Butler, L. J., Cook, M. K., Verma, S. M., Paul, M. A., Fields, B. S., Keteli, G., Sykora, J. L. \& Yee, R. B. (1988). Growth supporting activity for Legionella pneumophila in tap water cultures and implications of hartmennellid amoebae as growth factors. Appl Environ Microbiol 54, 2677-2682.

Weekers, P. H. H., Bodelier, P. L. E., Wijen, J. P. H. \& Vogels, G. D. (1993). Effects of grazing by the free-living soil amoebae Acanthamoeba castellanii, Acanthamoeba polyphaga and Hartmannella vermiformis on various bacteria. Appl Environ Microbiol 59, 2317-2319.

Wright, R. T. \& Coffin, R. B. (1984). Measuring microzooplankton grazing by its impact on bacterial production. Microbiol Ecol 10, 137-150. 